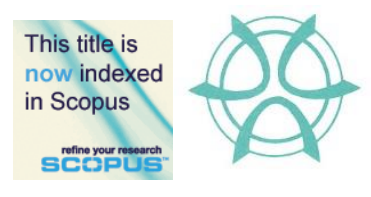

PLANNING MALAYSIA:

Journal of the Malaysian Institute of Planners

VOLUME 15 ISSUE 3 (2017), Page 27 - 38

\title{
ASSESSMENT OF BUBBLES IN THE MALAYSIAN HOUSING MARKET
}

\author{
Rohayu Ab Majid ${ }^{1}$, Rosli Said ${ }^{2}$, \& Chong, J.T.S \\ ${ }^{1}$ UNIVERSITI TEKNOLOGI MARA, MALAYSIA \\ ${ }^{2,3}$ UNIVERSITY OF MALAYA, MALAYSIA
}

\begin{abstract}
Property cycle and housing bubble have been a noteworthy subject of discussion since decades ago. The economic and business cycles have been closely associated with the property cycle as the economic and business factors have certain definite effects on the property market. At some point of the property cycle, the housing bubble will occur. The housing bubble is a trend of unreasonable increase of house prices where the increase is supported by factors that are not economics related. It causes the house prices to be intolerable in terms of housing affordability and the bursting of this housing bubble would lead to the crash of the property market. This paper focuses on using the economic indicators to identify the phases of the residential property cycle in Malaysia from the year 2000 to 2012. Having done so, housing bubbles were analysed using ratio analysis for the year 2012. The results show that housing bubble is yet to become a significant threat to our national property market as it only affects certain areas and housing types.
\end{abstract}

Keywords: Property cycle, housing affordability, housing bubbles, ratio analysis

Date Received: $5^{\text {th }}$ April 2017

Date of Acceptance: $28^{\text {th }}$ September 2017 
Rohayu Ab Majid, Rosli Said, \& Chong, J.T.S

Assessment of Bubbles in the Malaysian Housing Market

\section{INTRODUCTION}

The existence of housing bubble has been a debatable issue in Malaysia. In relation to the housing bubble, the property cycle first has to be analysed in order to determine the possibility of a bubble in the housing market. Undoubtedly, the housing price in Malaysia has been increasing rapidly in recent years. As such, issues and concerns have been raised over the affordability and the property crash of the housing market. The objective of this paper is to determine the existence of property bubble in relation to a property cycle for the period of 1990 to 2012 .

Several approaches have been previously conducted on this matter. For this paper, the indicators to construct the phases in a property cycle will first be identified. Then, the property cycle will be studied based on the economic indicators which will foresee the present and future economic performance. In this case, the study of the business cycle is considered to be one of the applications of economic indicators. By determining whether a bubble exists in our housing market, this prepares the market for any significant economic impact.

\section{RESEARCH BACKGROUND}

\section{Property Cycle: Definition}

The analogy of a property cycle is properly defined in the RICS (1994), in which the property cycle is defined as the observations of the rate of all property total return which show irregular but recurrent fluctuations which include other indicators that are fundamentals to the property activity. The surrounding, neighbourhood and types of property have always been the reason of the property cycles being unique and different (Witten, 1987). A property cycle has been defined relative to the business cycle. One of the very first studies done on property cycle was by Hoyt (1933) in the early thirties in Chicago. From thereon, many researchers followed suit and revised the analysis on property cycles.

\section{Phases in Property Cycle}

Majid and Said (2013) identify five different types of phases in a property cycle from various literature throughout the decades. From the literature of Witten (1987), the Property Cycle I is identified with four stages. It is described to be revolving according to the equilibrium line. Firstly, the adjustment phase will meet the line of equilibrium. From this point onwards, the demand phase begins with the need for supply in the market to expand. This phase positively attracts more development of properties in the market to furnish a supply for the demand. This would be known as the developmental phase. However, continued developments cause an excess of supply which leads to the next phase of overdevelopment. 
Property Cycle II is discussed based on findings by Mueller and Laposa (1994). It has four phases; decline, initiation, expansion and contraction. It is said to be an improvement of the previous property cycle.

Property Cycle III is elaborated through discoveries by Bean (1996) that involve five phases. Taking into consideration the market elements, this cycle is a better reflection as compared to the previously discussed cycles. This property cycle focuses on the position of the phases in the real market and ignores the equilibrium line.

Property Cycle IV as conveyed by Yew (1999) has no equilibrium line and has four phases namely expansion, peak, contraction and bottom. It reflects the combination of Property Cycle I and II with no equilibrium line as illustrated by Property Cycle III.

Property Cycle V is explained through definitions by Pyhrr, Roulac and Born (1999). It involves only two phases which are peak and bottom. Seemingly simple, the cycle incorporated inflexion points, amplitude and duration of each phase.

Property Cycle VI is described based on studies by Price Water House Coopers (2000). It has four phases which are decline, expansion, peak and contraction. By adapting existing cycles, the market position is being identified at different phases.

From the cycles, all phases can be classified into three category which is the expansion, equilibrium and contraction (Majid \& Said, 2013). In addition, Said and Majid (2014) studied the Malaysian housing cycle from 1990 to 2012, and found that the present cycle becomes the longest housing cycle in the Malaysian history.

\section{Property Cycle Indicators}

Brown and Kim (2001) used conventional spectral analysis techniques which analyse the evidence of cycles and co-cycles in property and financial assets where they have suggested that different indicators would behave differently over the four identified property cycle phases (recession, contraction, recovery and expansion).

In the local context, Chong (2006) shows that the indicators that are significant in determining the stages in property cycle are as follows:

a) GDP of all sectors

b) GDP of construction sector

c) Total loan by banking system

d) Number of residential property transaction

e) Malaysia House Price Index 
Rohayu Ab Majid, Rosli Said, \& Chong, J.T.S

Assessment of Bubbles in the Malaysian Housing Market

Chong (2006) used bivariate analysis to determine whether the said indicators have significant relevancy to the construction of the property cycle. In her analysis, she concluded four phases which are boom, bubble, trigger and crash.

Said et al. (2014) further studied the Malaysian housing cycle and identified the impact of Asian financial crisis on the housing market. They found that the performance of the Malaysian housing market is determined by the housing finance and macroeconomic variables. They employed Vector Autoregressive Approach and Causality test to identify the relationship between the variables in the short and long runs of the housing cycle. They further concluded that the occurrence of shock during the Asian financial crisis severely affected the housing market performance.

\section{Housing Bubble: Definition}

A housing bubble is defined as the circumstances where the selling price of the property is high only by reason that it will be greater in the future without being justified by fundamental factors (Stiglitz, 1990).

Case and Shiller (2004) describe housing bubble as when prospective buyers are starting to accept the high house price that is too expensive for them in thoughts that they will be compensated by the great increase in value in the future.

Kindleberger (2000) claims that a bubble is a continuous distinct rise in the price of an asset or range of assets, with initial situations forming anticipations of further rises and luring more prospective buyers. This rise is usually followed by a financial crisis caused by the reversal of expectations and a sharp decline in price.

It has also been described as expectations being integrated with the price hike and it will continue to attract buyers to pay more to satisfy the expectation itself (Baker \& Wurgler, 2002).

Most of the researchers managed to establish the housing bubble key concepts; the departure of prices from the fundamental value (Garber, 2000), a large drop in prices after the bubble pops (Siegel, 2003) and the market prices are not justified by fundamentals (Smith \& Smith, 2006).

Xiao (2010) in his housing bubble research in China has described that without a doubt, housing prices cannot go up forever. When people perceive that prices have stopped going up, past support for their acceptance of high housing prices will break down, and housing prices will then fall due to the diminished demand.

A housing bubble is an ongoing house price elevation, driven by nonfundamental economic indicators which are purely stimulated by expectation and speculation of the players in the housing market. 
PLANNING MALAYSIA

Journal of the Malaysia Institute of Planners (2017)

\section{Impact of Housing Bubble}

The motivation to spend because of the increasing of household consumption is a positive situation for the economy. The growing house price motivates the consumer to spend, which increases the household's consumption (Baker, 2002). However, this is only perceived to be a short-term positive impact which would eventually present itself as mostly negative after the bubble has burst.

On the negative impacts, Thornton (2006) describes the effects of the housing bubble. He mentions that the harm created by the bubble spreads to labour because of unemployment and creates a loss of value to owners of capital, particularly in housing-related industries. At the individual level, many people are forced into bankruptcy. On the macroeconomic level, the bursting of the housing bubble can send the overall economy into recession or depression. Further into his research, Thornton (2006) adds psychological consequences as one of the effects of the housing bubble when the situation turns from home buyers being confident in their purchasing decision to home buyers being fearful of capitalism after the burst of a housing bubble.

At the burst of the bubble, the mortgage supplies would decrease and this would cause instability in the economy. According to Xiaojing \& Sun (2006), bank lending is associated with real estate cycles and the bursting of bubbles, which results in significant non-performing loans, financial instability and crises in the economy. In funding the property market, banks and financial institutions would suffer overexposure and losses billions of dollars (Kallberg, Liu \& Pasquariello, 2002).

According to McKibbin \& Stoeckel (2006), what follows the house price fall is the decline in household consumption. Upon the burst, the consumer will be intimidated with less wealthy and control spending. In the local context, Said and Majid (2014) provide an understanding of the housing market and nature of house price variations as a result of the occurrence of shock in the Malaysian housing market.

\section{Measuring Housing Bubble}

Himmelberg, Mayer and Sinai (2005) explain how to assess the state of house price to identify whether the bubbles exist in the housing market and found that the house prices are more sensitive to changes in the real interest rate. Such approach was also employed by Xiao (2010) where he used ratio approach including the analysis of the house price-to-income ratio, house price-to-rent ratio and vacancy rate. For house price-to-income ratio, the purchasing power of home buyers is inversely proportionate to this ratio.

House-price-to-rent ratio is the relationship between the housing price and the rental rate. It shows how much house price has deviated from its real value. For vacancy, a higher rate would indicate that the unoccupied spaces amount to a struggling property market condition. 
Rohayu Ab Majid, Rosli Said, \& Chong, J.T.S

Assessment of Bubbles in the Malaysian Housing Market

Another commonly used approach is the Vector Error Correction Model where values are compared with the equilibrium value taking into consideration some major economic determinants in an effort to determine the existence of a bubble in the housing market. By using the method, the long-term and short-term trends of housing price dynamics can be studied. The revised model by Chen $e t$ al. (2013) consisting of housing demand and housing supply equations. Chen $e t$ al. (2013) suggest that the equilibrium condition is when the demand of housing market is equal to the supply of housing market.

\section{METHODOLOGY}

\section{Data Collection}

The data are mainly based on the secondary data of macroeconomic indicators from the year 1990 to 2012 (annually). The indicators were used in the property cycle and housing bubble analysis. The main sources of data were from the government's official publications namely the Department of Statistics, Department of Valuation and Property Services and Central Bank of Malaysia.

\section{Data Analysis}

This study involves three stages of analysis. The first analysis was the Bivariate Correlation analysis through the Pearson product-moment coefficient of correlation using SPSS. This analysis was used to determine the indicators that have a significant relationship with the housing price by using Malaysian House Price Index (MHPI) as a predetermined indicator. The MPHI and other collected data of different indicators such as Gross Domestic Product for all sectors, Gross Domestic Product for Construction Sector, total housing loan approved, the volume of housing transaction, base lending rate and unemployment rate were analysed in a correlation matrix to study the strength of their relationships with the housing price. Only indicators with significant correlation were taken into consideration.

The second analysis was based on the indicators identified to have a strong relationship with the housing price. Thereafter, these indicators were studied together to determine the phases of property cycle over the projected period.

The third analysis was the determination of housing bubble in different geographical locations based on different types of housing in the year 2012. This was done by using the ratio analysis which was commonly used by researchers such as Xiao (2006). The ratio analysis includes median house price to annual median income and average house price growth rate to GDP growth rate. 
PLANNING MALAYSIA

Journal of the Malaysia Institute of Planners (2017)

\section{RESULTS}

\section{Correlation Matrix: Indicators}

Table 1 shows the values in the form of the correlation matrix for the predetermined indicator of MHPI and the selected indicators to be tested for significant value in the housing price.

Table 1 Correlation Values

\begin{tabular}{ll}
\hline Indicators & r-value \\
\hline GDP for all sectors & $\mathrm{r}(13)=.96, \mathrm{p}<.001$ \\
GDP for construction sector & $\mathrm{r}(13)=.97, \mathrm{p}<.001$ \\
Total housing loan approved & $\mathrm{r}(13)=.95, \mathrm{p}<.001$ \\
Volume of housing transaction & $\mathrm{r}(13)=.97, \mathrm{p}<.001$ \\
Base lending rate & $\mathrm{r}(13)=-.068, \mathrm{p}=.826$ \\
Unemployment rate & $\mathrm{r}(13)=-.472, \mathrm{p}=.103$ \\
\hline
\end{tabular}

The correlation value shows that only the base lending rate and unemployment rate have no significant correlation with the Malaysian Housing Price Index. The GDP for all sectors, GDP for the construction sector, the total housing loan approved and the volume of residential transactions all have a significant positive correlation to the MPHI and all the coefficients are close to a linear relationship.

\section{Housing Cycle: Phases}

Figure 1 shows the trend of housing cycle from the year 2001 to 2012 which was plotted from the annual price growth rate. The results imply that the main contributory factors that affect the housing cycle during the trigger phase (20012004) were the tax relief and the waiving of the Real Property Gain Tax (RPGT) and Stamp Duty. During the Stagnant period (2004-2007), the main contributory factor was mainly the tax incentives given by the government. However, during the Minor Crash (2007-2009), the negative growth occurred as a result of the Subprime Crisis where the government started to introduce the stimulus packages as well the liberalisation of cement industry. Finally, during the boom period (2009-2012), the price increased significantly resulted in the lifting of RPGT exemption, the reduction of the loan-to-value ratio to $70 \%$ and the second introduction of the stimulus packages. The trends imply that government intervention is crucial in each phase of the housing cycle in order to stabilise the housing price. 
Rohayu Ab Majid, Rosli Said, \& Chong, J.T.S

Assessment of Bubbles in the Malaysian Housing Market
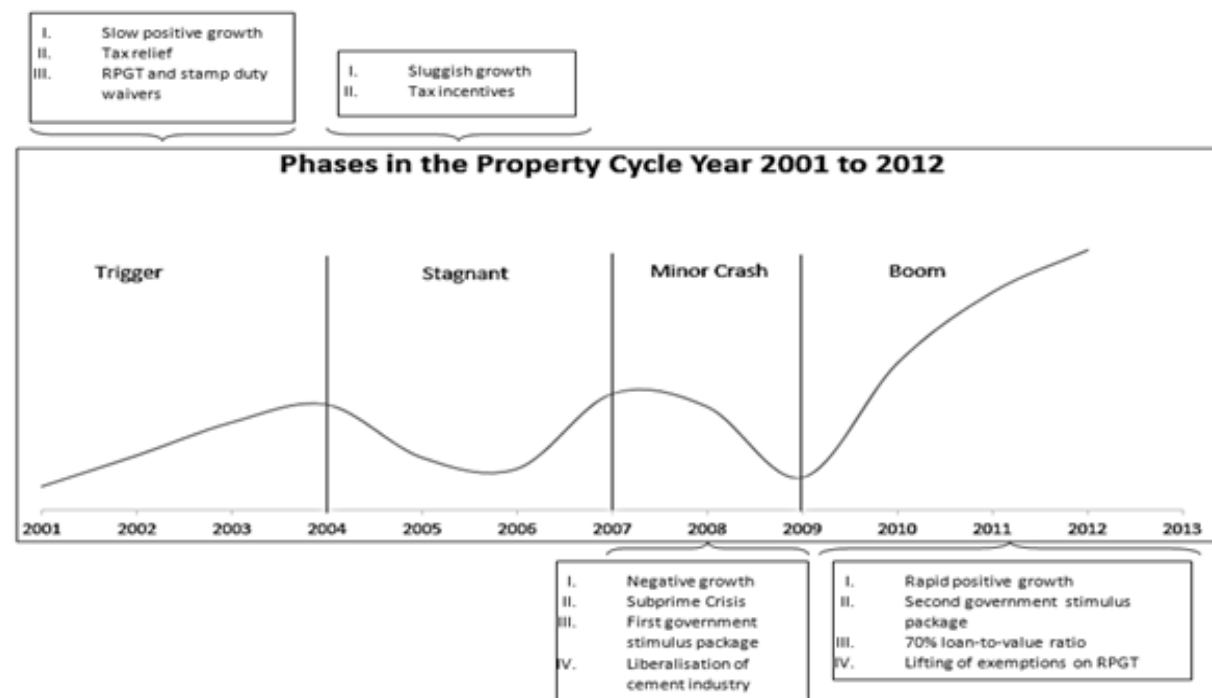

Figure 1 Housing Cycle

\section{Housing Bubble: Price-to-income ratio}

The indication of a housing bubble can be analysed using the price-to-income ratio and the average house price-to-growth of GDP ratio.

For the price-to-income ratio, the study was subjected to the availability of data for each state. Therefore, five states were selected for this purpose. The type of housing taken into consideration is $1-1 \frac{1}{2}$ storey terrace, cluster, condominium and flat. According to the World Bank (1993), the ratio of 3 to 6 is normal while higher ratios are indicative of a housing bubble. Higher ratios could indicate the increase in difficulties to meet mortgage requirements and this increases the pressure on the housing market.

Table 2 shows the significant ratio of median house price to median annual income in each selected state. The ratio higher than 6 indicates the existence of housing bubble.

Table 2 Ratio of median house price to median annual income of the selected states

(2012)

\begin{tabular}{lccc}
\hline \multicolumn{1}{c}{ Name of } & \multicolumn{3}{c}{ Type of Housing } \\
\cline { 2 - 4 } \multicolumn{1}{c}{ State } & $1-1 \frac{1}{2} 2$ storey terrace & Cluster & Condominium \\
\hline W.P. Kuala Lumpur & - & - & 6.19 \\
Johor & - & 10.51 & - \\
Penang & - & - & 9.13 \\
Sabah & - & - & 8.73 \\
Sarawak & 6.98 & - & 7.12 \\
Source: Property Market Report and Department of Statistics (2014)
\end{tabular}


PLANNING MALAYSIA

Journal of the Malaysia Institute of Planners (2017)

\section{Housing Bubble: Average House Price-to-Growth of GDP ratio}

Table 3 shows the ratio of the growth of average house price to the growth of GDP. Again, the analysis was subjected to the availability of data and ten states were selected for this purpose. The growth in house price should have been less than the economic growth (Himmelberg, Mayer and Sinai, 2005). The ratio of 1 to 2 forms the warning line for housing bubble while any ratio more than 2 is indicative of a housing bubble.

Table 3 Growth of Average House Price to Growth of GDP Ratio

\begin{tabular}{lc}
\hline \multicolumn{1}{c}{ Name of State } & Ratio \\
\hline W.P. Kuala Lumpur & 2.0 \\
W.P. Labuan & -0.4 \\
Selangor & 1.5 \\
Johor & 3.2 \\
Penang & 4.2 \\
Perak & 0.7 \\
Negeri Sembilan & 1.9 \\
Malacca & 1.6 \\
Kedah & 1.0 \\
Pahang & 0.8 \\
\hline
\end{tabular}

The results show that not all the selected states have a ratio of higher than 2. Most states are within the normal range, and only Johor and Penang show indication of the existence of a housing bubble. The results signify that bubble only exists in certain states. The impact of such analysis suggests that if the bubbles continue to reach a full-blown state in years ahead, the housing market will fall into another crisis due to oversupply.

\section{DISCUSSION}

The first part of the study determines the relevant indicators influencing the phases of the residential cycle where the results showed that only certain economic indicators have significant influence. The identified indicators are then used to study the phases of the residential cycle in Malaysia from the year 2000 to 2012. From the findings, it can be concluded that from the year 2000 to 2012, the housing market experienced the phases of trigger, stagnant, minor crash and boom. The results imply that the residential property cycle has yet to complete its full swing of the cycle within the study period. Hence, judging from the boom phase, the housing bubble should still be at a considerably low level.

Also, it is noted that some of the indicators may drive the housing market slightly earlier or later than the other indicator because of their leading, lagging or coinciding characteristics. Nevertheless, the time of response has only shown a year or two years of difference before reaching the trend of the following phase. GDP proved to be the leading and coinciding indicators which command the most 
Rohayu Ab Majid, Rosli Said, \& Chong, J.T.S

Assessment of Bubbles in the Malaysian Housing Market

sensitive response to the changes in the market. On the other hand, the housing price picked up slightly at a slower pace because of its lagging characteristics. The third part of the analysis revealed that most of the states in Malaysia are still at a normal line in terms of the occurrences of the housing bubble.

\section{CONCLUSIONS}

The housing price in Malaysia had been on the rise from the year 2009 to 2012 but noticeably with slower growth in recent years. At the same time, there have been anticipation and expectation on the occurrences of the housing bubble in the residential market in states like Kuala Lumpur, Johor and Penang where the housing price has been growing positively at exponential rates. The cycle follows the trend observed in other developed countries where the cycle usually reaches its full swing between $8-10$ years.

The property cycle shows that Malaysia is experiencing boom phase starting from the year 2009 to 2012 but expects to slow down afterwards. As such, Malaysia is not supposed to be experiencing a full-blown housing bubble since it was still in the boom phase up to the year 2012. Thereafter, the ratio analysis shows that the occurrences of a housing bubble are not significant at the national level but only show traces at the micro level of certain states and housing types.

\section{REFERENCES}

Baker, M., \& Wurgler, J. (2002). Market timing and capital structure. The Journal of Finance, 57(1), 1-32.

Bean, C. (1996). The convex Phillips curve and macroeconomic policymaking under uncertainty. London School of Economics and HM Treasury, November.

Brown, G., \& Kim, H. L. (2001). Cyclical relationship between commercial real estate and property stock prices. Journal of Property Research, 18(4), 309-320.

Case, K. E., \& Shiller, R. J. (2004). Is there a bubble in the housing market? Retrieved from https://www.brookings.edu/bpea-articles/is-there-abubble-in-the-housing-market/.

Chen, R. D., Gan, C., Hu, B., \& Cohen, D. A. (2013). An empirical analysis of house price bubble: A case study of Beijing housing market. Research in Applied Economics, 5(1).

Chong, H. P. (2006). A study on the current residential property cycle in Malaysia, University of Malaya, Malaysia. (Bachelor dissertation).

Garber, P. M. (2000). Famous first bubbles: The fundamentals of early manias. Cambridge, MA: MIT Press.

Himmelberg, C., Mayer, C., \& Sinai, T. (2005). Assessing high house prices: bubbles, fundamentals and misperceptions. Journal of Economic Perspectives, 19(4), 67-92 
Hoyt, H. (1933). One hundred years of land values in Chicago. Chicago: University of Chicago Press.

Kallberg, J. G., Liu, C. H., \& Pasquariello, P. (2002). Regime shifts in Asian equity and real estate markets. Real Estate Economics, 30(2), 263-291.

Kindleberger, C. P. (2000). Manias, panics, and crashes: a history of financial crises. The Scriblerian and the Kit-Cats, 32(2), 379.

Majid, R. A., \& Said, R. (2013). Impak kitaran harta tanah dalam pasaran perumahan. Journal of Design and Built Environment, 12, 1-8.

McKibbin, W., \& Stoeckel, A. (2006). Bursting of US housing bubble. Economic Scenario (14)

Mueller, G. R., \& Laposa, S. P. (1994). Evaluating real estate markets using cycle analyses. Annual Meeting of the American Real Estate Society 1994, Santa Barbara, USA.

Pyhrr, S. A., Roulac, S. E., \& Born, W. L. (1999). Real estate cycle and their strategic implication for investors and portfolio managers in the global economy. Journal of Real Estate Research, 18(1), 7-68.

Price Water House Coopers. (2000). Real Estate Value Cycle First Quarter 2000, Real Estate Value Cycle. Retrieved from http://www.pwc.com

RICS (1994). Understanding the Property Cycle. London: The Royal Institution of Chartered Surveyors.

Said, R. \& Majid, R.A. (2014). Housing market: What does the Malaysian house price index tell us about the housing market performance? International Surveying Research Journal, 4(1).

Said, R., Adair, A., McGreal, S., \& Majid, R. (2014). Inter-relationship between the housing market and housing finance system: Evidence from Malaysia. International Journal of Strategic Property Management, $18(2), 138-150$.

Siegel, J. J. ( 2003). What is an asset price bubble? An operational definition. European Financial Management, 9(1), 11- 24

Smith, M. H., \& Smith, G. (2006). Bubble, bubble, where's the housing bubble? Brookings Papers on Economic Activity 1, The Real Estate Bubble in the 2000's - Housing Market Indicators. Retrieved from http://edinformatics.com/real_estate/real_estate_bubble.htm

Stiglitz, J. E. (1990). Symposium on bubbles. The Journal of Economic Perspectives, 4(2), 13-18.

Thornton, M. (2006). Cantilion on the cause of the business cycle. The Quarterly Journal of Austrian Economics, 9(3), 45-60.

Valuation and Property Services Department (1990 - 2014). Property Market Report (PMR) (1990-2014). Ministry of Finance Malaysia, Putrajaya.

Witten, R. G. (1987). Riding the inflation cycle. Real Estate Today, (August), 4248. 
Rohayu Ab Majid, Rosli Said, \& Chong, J.T.S

Assessment of Bubbles in the Malaysian Housing Market

World Bank (1993). Housing: Enabling markets to work. Washington, DC: World Bank

Xiao, Q. (2006). Property market bubbles: some evidence from Seoul and Hong Kong (Doctoral dissertation). School of Humanities and Social Science, Nanyang Technological University.

Xiao, S. (2010). Is there a bubble in China's housing market? (Masters dissertation). KTH Architecture and the Built Environment, Stockholm.

Xiaojing, Z., \& Sun, T. (2006). China's property cycles and financial stability. Economic Research Journal 1: 003.

Yew, K. Y. (1999). Forecasting on property cycle: a quantitative approach. University of Malaya, Kuala Lumpur. (Bachelor dissertation). 